Kom, 2014, vol. III (1) : 163-177

UDC: $28-183.5$

159.953.5:28-1

Review article

\title{
Place of Learning in Prophetic Thought
}

\author{
Ahmad Salahshoori \\ Faculty of Literature and Humanities, \\ Bu-Ali Sina University, Hamadan, Iran \\ Masoomeh Khonakdar Tarsi \\ Faculty of Literature and Humanities, \\ Bu-Ali Sina University, Hamadan, Iran
}

\begin{abstract}
With the Renaissance Era there came a change in the philosophical and scientific worldview, which provided a mechanistic view of the universe, and the same goes for human history, where a new phase began that led to the radical changes in human history and education. The advent of the Newtonian era led to its laws and rules replacing the divine law and discursive wisdom replaced the divine will and God and sought the rule of Newton's and mathematical laws; material concepts were replaced by the metaphysical concept. One of the concepts that influenced the worldview is the concept of learning. Most theories in psychology see the brain as the learning center, because they believe that the brain is the center of perception and cognition; however, in the viewpoint of prophetic thought it is the heart that is the center of learning and the brain is seen just as the sensory center. This paper examines the prophetic vision about the center and place of learning and presents a critical approach to psychology theories.
\end{abstract}

Keywords: place, learning, brain, heart, prophetic thought

\section{Introduction}

It can be said that in the historical evolution from Thales of Miletus to Plotinus, the center of scientific evolution was first in ancient Greece, then it

Corresponding author: ah.salahshoor@gmail.com

Corresponding author: masi_kh2@yahoo.com 
was moved to Rome and, as the Roman Empire gradually weakened, it was handed over to the church.

We can say that science began with Aristotle. He put emphasis on logic and reviewed the relation between concepts based on induction and deduction. In Aristotle, the idea of proportion determined the relation between concepts. Nature is dependent on causality law and the mind is dependent on reason and logic and the final causality is very important. Induction can increase science. In Aristotle's philosophy, the essence and nature of phenomena are very important and laws take a back seat to them (Kuhn 2005: 54). In Aristotelian times, science referred to eternal facts and did not have hypothetical essence. For example, Plato believed we should not begin with hypothesis but we should query hypothesis. Also, Aristotle believed that theory and practice were the same. In sum, both Plato and Aristotle held theory as an ultimate position and considered knowledge as unity. Science at the time of Aristotle meant the supreme method of life style. Science sought facts for facts and for this reason facts had a universal meaning and related to social and natural aspects of life. In addition, in this age science was an activity that was respectful in itself and was not separate from moral and individual.

The aim of science in Aristotelian age was good life, happiness and finally the actualization of wisdom. The content of liberal arts that in turn comprises trivium and quadrivium also contained philosophy and teleology, mathematics, history and literature. Teaching methods were inductive and deductive, including dialectic, discourse and observation. In sum, in Aristotelian age the emphasis was on the pluralistic method. The church propounded the assumption of the primitive sin made by Adam to resort to irregular severity in bodily dimension. This led scientific evolution trends to continue into the Renaissance. With the emergence of Renaissance, the second age of science began. It was called the mechanical, Newton's Age of science and philosophy. The most important feature of this age was the emphasis on mathematics and, owing to different research done by scientists such as Copernicus and Galileo, the final causality was replaced by efficient causality and logic by mathematics, especially with mechanical motion (Golshani 2001: 38). At that time, thinkers such as Galileo, Newton, Bacon and etc. had the position to explain all scientific branches and contexts based on the material and as Renaissance developed, they equaled all mental states with physical states of the mind and as the theory of evolution emerged, the material trend increased in such a way that they did not differentiate between humans and animals (Karbasi-zadeh \& Sheykh Rezaei 2011: 42).

According to Newton, the world was rational, predictable, specified and had mechanical order and every phenomenon was related to a specific cause (Mason 2008: 41). 
Features such as predictability, causality, modeling, control, universality, linearity, continuity, constant and objectivity all help us see the world as a machine in which there are balance, instrumental rationality and a closed system and controllable use for discovery of scientific laws.

Newton's scientific theory was derived from scientific works of philosophers such as Francis Bacon (1561-1626), Thomas Hobbes (1588-1679), Rene Descartes (1596-1650) as well as other great works. In this age, methodology, especially the scientific and technical ones, criteria centered education, utility centered education, applied theory, natural theory, hypothetical approach to science, fragmentation between theory and practice and finally rejection of ultimate centered education, all had a sound value. World appreciation based on the material concept led materialism to be considered as one of the main methods of acquiring science and from then on, a materialistic worldview has dominated the universe. It started with a positivistic insight in natural sciences and later penetrated humanistic sciences and had consequences such as spiritual and human thought denial; and as it assumed that humans were material, it increased the value of human biological states and spiritual states were ignored. As mathematics developed and quantity dominated in all sciences, the perception of metaphysical concepts weakened in such a way that quantity dimension kept on strengthening whereas faith in the holy affair weakened, so that only the quantity dimension became the real mode; the new science became just mathematics and empirical science and only the empirical cognition was known as the real cognition (Guenon 2006: 61-70).

The third period of science began with Quantum physics. In this age, thinkers and scientists such as Werner Karl Heisenberg (1901-1976), Albert Einstein (1879-1955), Thomas Samuel Kuhn (1922-1996), Karl Raimund Popper (1902-1994), Michel Foucault (1926-1984) and Jacques Derrida (1930-2004) played an important role and introduced new ideas in the world of speculation. In this age features such as anti-absolutism, uncertainty, relativism, complexity, un-linearity, and false ability were laid great emphasis on and it was assumed that one phenomenon may have more than one consequence and cause (Golshani 2001: 46).

Scientific theories according to the teachings of every one of these were based on holism, interchangeable causality, pluralism, subjectivity, integration between observation and theory, self-regulation, focus on relation between phenomena, discourse-centered education, multi-dimension education, down-up education, local control, systematic research activity, gradual evolution, process centered education and synergy. Upbringing in the modern age was completely blocked in the meaningful and spiritual world and its source of inspiration became a subject. In other words, inspiration source and upbringing power in this period were nothing but the human personal spirit 
which assumed itself independent; but the real meaning of upbringing in Islamic viewpoint goes much further than personal source and a genteel or educated human is the emanation of divine mercy. The conception of learning is one of upbringing categories. This conception has been deviated and changed because of the Newton's period worldview. This article is trying to study the position and center of learning in Islamic viewpoint, particularly so in the prophet thought, to adjust prophet speech to the benevolent Qur'an and to compare it with new psychological schools.

\section{The Concept and Place of Learning in Psychology Approaches}

Learning concept is one of the basic concepts in the new age. Today, psychologists believe that the foundation of learning is in perception and that in this process physical stimulus, organism and response are examined. Most approaches of psychology believe that the brain is the learning center. Some approaches, like behaviorists', see learning as a connection between stimulus and response. Here, learning refers to changes in object behavior. In cognitive approaches it is believed that learning relates to cognitive and mental processes, such as making changes in organization of information, perception and understanding of the meaning (Seif 2006: 258).

Information processing approach believes that learning is achieved when all the information from short-term memory is transferred to long-term memory (ibid.: 316). Discussion of perception in psychology is a process that begins with chemical and physical stimuli (Iravani \& Khodapanahi 2006: 15-18). In psychology, each stimulus stimulates the senses. So, every sense may be stimulated by the stimulus. Therefore, the feeling takes shape and then it forms perception. For example, one picture is transmitted to the brain by the sense of sight that is formed in the way of feeling. Then the brain analyzes it and its image is recognized. This is called perception.

Thus a series of stimuli is formed because of these senses and it causes the brain to form some perceptions and it is the brain that can comprehend. So, according to the psychological viewpoint, the brain is the center of perception and the base of learning. However, in the prophet thought viewpoint, the heart is the center of learning while the brain is the center of feeling. Following this path, we investigate the literal meaning of the heart and then the Qur'anic viewpoint and the prophet thought and finally we study and criticize the position of learning in psychology: the concept of learning is one of the fundamental concepts in modern era. Nowadays, psychology considers the sense conception as the base of cognition and learning; in this process, it studies physical stimulus, beings and the answer. In most psychological 
approaches, the brain is considered the center and base of learning. Some approaches, such as behaviorists', think of learning as a kind of association or link between the stimulus and response and, here, learning is a kind of creating change in people's explicit behavior. Some others, like cognitivists, believe that learning is creating change in cognitive structure and mental processes such as organizing information, comprehending affairs, comprehending meaning and etc. (see: ibid.: 258). The news-making theory believes that learning is realized when the received information passes all memory stages and enters long term-memory (see: ibid.: 316 ).

\section{Literary Meanings of Heart}

The literal meaning of the heart is pure and noble part of anything, and as human heart is the most noble and valuable part of human existence, it is called heart (al-Jawhary 1998: 80). Heart has the talent of comprehending and witnessing the exalted realities apart from mental imaginations. Heart is the meeting focus of the light of mind and the light of revelation; it is the place for thought development and internal evolution (Raghib Isfahani 1985: 32). Heart is the environment for acquiring science and provision for God-fearing and it is the house of faith. Perhaps it can be said that heart is one of spirit expressions such as mind or ego and in religious thinkers and theosophists' viewpoint, there are four words whose meanings have a close connection with each other and they are: ego, heart, mind, and spirit. For instance, when al-Ghazali discussed human ego and spirit, he mentioned four words, namely heart, spirit, ego and mind, and he believed that the disability to differentiate these four words was the source of many mistakes and errors.

Heart (midst): they gave two meanings for heart: in the first meaning, heart was the same pinyin-like flesh in the left side of the chest and the cattle have this heart; and in the second meaning, heart was a spiritual delicacy which belongs to this bodily midst and the human reality is this heart. Whenever we mention heart, we have in mind the second meaning. This second meaning of heart is the human spirit which is the divine safekeeping and the mettle which invites humans to theology (al-Ghazali 1973: III/14-15). Al-Ghazali mentioned two meanings of the spirit, too; he believed the first meaning of spirit to be the delicate body and its source is the animal spirit (animal ego) which is distributed in other body parts through springy vessels and is like a lamp which lights the house-like body; and he believed that the second meaning of spirit is the delicate knower and appreciator of the people. This spirit is of the same material as the angels' and is called the human spirit (the divine ego). It is single and immortal. This second meaning of spirit is the human reality. The Qur'an also mentions this spirit: "And 
they ask you, [O Muhammad], about the soul. Say, 'The soul is of the affair of my Lord. And mankind have not been given of knowledge except a little."' (Qur'an 17: 85), and the mind is not able to comprehend its nature and reality (17: 15-16).

Ego is expressed in two meanings: in the first meaning, it includes all ugly attributes of human and it is the origin of animal forces which are contrary to rational forces (17: 16). In the second meaning, ego is human essence and reality, but according to the differences between people, it changes to different attributes, such as superego, self-accusing soul and rest soul. The reason why this ego is considered human essence and reality is that the ego of a thing is its reality and the human reality is that essence which is the location of rational things and has appeared from the divine world; the second meaning is meant by ego in the sense of human essence (17: 16).

The word mind has been mentioned with two meanings: in the first meaning, mind means knowledge of the reality of affairs, and mind in this sense implies the science and knowledge which is acquired by senses and through reasoning. Thus the armies of this mind are the five senses. And the second meaning of mind is the power which is the proof of sciences and knowledge, and the mind with this concept is synonymous with the concept of speech ego; when the Prophet said the mind is the first creature which God created, he meant this mind; the second meaning of mind is acquired from insight and that knowledge should be acquired through the Intuition (17: 17).

Generally speaking, al-Ghazali and prophet thinkers used heart, spirit, ego and mind as names that imply one goal and purpose. Heart is sometimes called mind, sometimes internal insight, and sometimes the light of faith and certainty. He emphasized that we should not engage ourselves in the names, because terms are different and if we became involved in different names, some who have weak understanding and appreciation would assume that the disagreement is in the meaning.

Sometimes al-Ghazali used these four terms for the same meaning and by the equivalence of meaning of ego and spirit, he meant that the unity of ego came with the divine spirit and he considered this spirit as human virtue and honor and believed that this category is immortal and divine and it is because of this spirit and ego that human is the most honorable creature and the vicar of God on Earth and the head of all universe (see: 17: 17-19). But heart has two meanings in the Qur'an, too: the first meaning is an organ and it is the pearl-like organ in human body in the left side of all humans' chest. It is studied in human body organs anatomy; it is a very delicate and sensitive organ and if it is lost, all human senses are lost, too. The second meaning of heart is the human spirit which is the divine safekeeping inside the human body and the human mettle is hidden in it; the mettle which invites humans 
to theology and it is the human principle and the extremity of creatures and the creation world in the resurrection world: "Those who have believed and whose hearts are assured by the remembrance of Allah. Unquestionably, by the remembrance of Allah hearts are assured." (Qur'an 13:28).

\section{Heart and the Position of Learning in Prophet Thought Viewpoint}

In prophet thought viewpoint, heart is assumed to be the center of understanding and comprehension and intellect. In Imam Ali's speech in the $108^{\text {th }}$ saying in Nahj al-Balagha, he says:

"Inside human chest, a flesh part is hung which is the strangest organ in his body and it is his heart and this wonder is because incentives of wisdom and its opposite are gathered in it. Whenever the wishes appear in it, they will smite his greed and when the greed excites in him, the avidity perishes in him and when the despair dominates him, regret kills him and whenever wrath predominates him, his anger increases and whenever he is satisfied with something, he loses caution and if the fear dominates him, caution engages him to himself and when his affair is easy, he becomes ignorant and neglectful and if he gains some wealth, needlessness leads him to outburst and if he faces some disaster, impatience scandalizes him and if poverty and indigence dominates him, captivities occupy him and if he is hungry, weakness and disability paralyze him and if he has edacity, it would block his breathing; and in general terms, any deficiency would hurt him and any excess would corrupt him" (Ali ibn Abi Talib 1992: 338).

Numerous attributes of human ego characteristics, such as wisdom, greed, avidity, wrath, satisfaction, fear, extravagance, etc., are ascribed to heart and these discussions are the reason why there is a close connection between human ego and his heart and they are justifications for considering heart as the center of intellection and perception.

In this narrative, heart is one of the parts and organs which humans use to think with. Prophet-related thinkers believe that faith is divided in all body organs, that God has necessitated and divided and distributed faith for human organs and that there is no organ without faith in it; each organ has task that is designed only for that specific organ. Heart is one of the organs and it is the means of thought and understanding and intellect and it is the leader of body; other organs cannot begin or end any work without its idea and command, and what has become essential for heart is confession and 
recognition and decision and satisfaction and resignation to the belief that does not exist in nobody competent of worship except God. Here, Imam considered heart as the perception and learning center (see: al-Kulayni 1997: I/64). In their sayings, prophet-related thinkers interpreted heart as reason ${ }^{1}$; they interpreted heart as thought in $11^{\text {th }}$ piece of Ibn Hisham narrative in $7^{\text {th }}$ verse of sura Qaf: "O Hisham, God, Exalted, said in His Book: there is My mention in it for anybody who has heart, here heart means thought, and said: And We sent wisdom to Loghman, said: perception and intellect. Thus, here it can be understood that Imam considered heart as a center for comprehending and understanding realities" (ibid.: I/18). There are narratives in which it is specified that heart comprehends and recognizes through intellect: "Heart knows through intellect [...] He makes Hearts comprehend through Intellects." (ibid.). These discussions show that heart is the learning center and brain cannot in fact be a fundamental learning center. Prophet-related thinkers state in Tawhid al-Mufadhal that five senses are created for humans so that they can comprehend five phenomena and are capable of comprehending any of the phenomena. The five senses comprehend five phenomena and comprehending any of the phenomena is not neglected in him. So He created eye to see the colors. If there was not eye to sense colors, creating colors was useless. And $\mathrm{He}$ created ear to hear sounds. If there was sound and no ear to hear, what was the use of creating sound? And other senses are like this. If there were phenomena but there were no senses, creating them was useless. So, look out and see how everything has been created for something and there is a phenomenon for every sense and a sense for every phenomenon. There are also some items in every sense which are intermediate between sense and phenomena and sense is not gained without them. Such are light and air for seeing and hearing. If there was not light to enable the eye to see color, the eye would not see and if there was not air to transmit the sound to the ear, the ear would not hear (Mufadhal 2003: 85).

Here, prophet-related thought mentions the point that the reason for creation of the five senses was to comprehend the five phenomena. In psychology, every stimulus incites one of the senses, thus every sense is incited by a stimulus. The effect of these stimuli is transferred to the brain by sensory nerves and the feeling agent is formed; these feelings are then studied and the perception is shaped. For example, we see a picture of somebody. This picture is transferred to the brain by visionary sense and the feeling agent is shaped; then, the brain analyzes this action and the picture is recognized; this recognition is called perception. So, a series of stimuli is formed because

1 It should be mentioned that attributing heart to intellect shows that heart can do actions such as thinking, so the conclusion is that heart is learning center; in Islamic viewpoint, heart, ego and intellect are all aspects of the soul. 
of senses and these cause some perceptions from the brain and it is the brain which can comprehend. Thus, according to psychological view, brain is the perception center but in prophet-related thought viewpoint, brain is the feeling center and heart is the perception and learning center. Therefore, when expressing brain description, the prophet-related thought considers it as the source and center of human senses.

And if the brain which is in the head is opened to you, you will see it and it is curved to some covers, some above the others, so that they preserve it from any damage which could harm it and to keep it so that it does not move and does not become excited; and the bone in the head is like a helmet to protect it because if the head is hurt or is worn away in some place, it does not harm the brain. And He has grown hair on the head skin which is like a pelisse for it and protects it from heat and cold; so, he who has protected the brain like this can be no one but God who created it and made it the source of human senses that deserves protection and guarding; it is all because of the elevation esteem and eminence degree and highness rank which the brain possesses when compared to other body organs (see: al-Majlisi 1987: I/78). In these cases, it should be noted that in prophet-like thought, this point has been mentioned and senses are related to heart or soul. They affect each other, but in fact heart is the fundamental center for learning and other cases are considered as means and instruments for learning. The place of heart in body is seen as the place of Imam among people; all body organs are heart's agents. When the heart wishes to see, two eyes open for seeing or when hearing, two ears open for hearing; these members which act with heart stimulation do whatever the heart wishes. Prophet-like thinkers have bid: heart in the body is like a powerful leader whose orders must be obeyed among people in a country. Do you not see that all body organs - two eyes, two ears, nose, mouth, hands and feet are the soldiers of heart and under its control. Because, when human heart decides to see (according to its command), the human opens eyes; when he wishes to hear the ear announces its preparedness; when stomach wishes to smell, nostrils open and transfer that smell to the heart which is the center and when heart decides to speak, the tongue moves and when heart wishes to walk, the feet act, so all these organs and parts act according to heart's commands; they are its agents - and it is well-deserved that members of the Islamic community be like this toward their rightful Imam and all their actions be according to his command.

In Ayashi interpretation, Abdullah ibn Jafar quoted his brother, Musa ibn Ja'far who said human heart is anxious and stressful until it finds the reality; but when it reaches the right, it will be peaceful and fixed (see: al-Majlisi 1987: I/60; LIVII/68) and he read this verse in the Qur'an: 
"So whoever God wants to guide - He expands his breast to [contain] Islam; and whoever He wants to misguide - He makes his breast tight and constricted as though he were climbing into the sky. Thus does God place defilement upon those who do not believe." (Qur'an 6: 125)

\section{Heart from the Qur'an Viewpoint}

It can be said that heart implies to numerous states in the Qur'an and these states express this speech that heart is the center and base of learning; some verses which prove this speech right are mentioned below; some verses show that the place of comprehension and learning is heart and some verses are mentioned below that express the states and attributes which show the relationship between heart and place of comprehension and understanding. As an example:

Heart is considered the place of comprehending reality:

"And We have certainly created for Hell many of the jinn and mankind. They have hearts with which they do not understand, they have eyes with which they do not see, and they have ears with which they do not hear. Those are like livestock; rather, they are more astray. It is they who are the heedless." (7: 179)

The place of intellect and heart that is in some verses considered the place of acts and behavior or human power is attributed to the position of heart:

"And do not pursue that of which you have no knowledge. Indeed, the hearing, the sight and the heart - about all those [one] will be questioned." (17: 36)

"Then He proportioned him and breathed into him from His [created] soul and made for you hearing and vision and hearts; little are you grateful." (32: 9)

In some verses, heart, or midst, is a center which does not have the ability to think or comprehend:

"And We had certainly established them in such as We have not established you, and We made for them hearing and vision and hearts. But their hearing and vision and hearts availed them not from anything [of the punishment] when they were [continually] rejecting the signs of God; and they were enveloped by what they used to ridicule." (46: 26) 
"God has set a seal upon their hearts and upon their hearing, and over their vision is a veil. And for them is a great punishment." (2: 7)

"And give good tidings to those who believe and do righteous deeds that they will have gardens [in Paradise] beneath which rivers flow. Whenever they are provided with a provision of fruit therefrom, they will say, 'This is what we were provided with before.' And it is given to them in likeness. And they will have therein purified spouses, and they will abide therein eternally." (2: 25)

"And who is more unjust than one who is reminded of the verses of his Lord but turns away from them and forgets what his hands have put forth? Indeed, We have placed over their hearts coverings, lest they understand it, and in their ears deafness. And if you invite them to guidance - they will never be guided, then - ever." (18: 57)

"Or do they say, "He has invented about Allah a lie"? But if Allah willed, He could seal over your heart. And God eliminates falsehood and establishes the truth by His words. Indeed, He is Knowing of that within the breasts." (42: 24)

"Have you seen he who has taken as his god his [own] desire, and Allah has sent him astray due to knowledge and has set a seal upon his hearing and his heart and put over his vision a veil? So who will guide him after Allah? Then will you not be reminded?” (45: 23)

It should be noted that it is possible that different tools such as eye and ear are mentioned in some verses; however, these are considered as heart's tools and instruments, too. For example, in chapter an-Nahl, verse 78, it is mentioned that eye and ear are among the actions of heart and these two are among heart's tools. First we see or hear something, then heart (mind) thinks about it, thus the work of heart is usually supreme to the work of eye or ear. So, even if eye and ear have a role in this regard and open us to wisdom, these are all tools of heart for comprehension and cognition. Characteristics contrary to heart are attributed to heart in some verses and they all show that heart can be the center and position of learning and comprehension:

"In their hearts is disease, so Allah has increased their disease; and for them is a painful punishment because they [habitually] used to lie." (2: 10$)$ 
"And they said, 'Our hearts are wrapped.' But, [in fact], Allah has cursed them for their disbelief, so little is it that they believe." (2: 88)

"And [We cursed them] for their breaking of the covenant and their disbelief in the signs of Allah and their killing of the prophets without right and their saying, 'Our hearts are wrapped'. Rather, God has sealed them because of their disbelief, so they believe not, except for a few." (4: 155)

"Then do they not reflect upon the Qur'an, or are there locks upon [their] hearts?" (47: 24)

"So have they not traveled through the earth and have hearts by which to reason and ears by which to hear? For indeed, it is not eyes that are blinded, but blinded are the hearts which are within the breasts." (22: 46)

"O Messenger, let them not grieve you who hasten into disbelief of those who say, 'We believe' with their mouths, but their hearts believe not, and from among the Jews. [They are] avid listeners to falsehood, listening to another people who have not come to you. They distort words beyond their [proper] usages, saying 'If you are given this, take it; but if you are not given it, then beware.' But he for whom God intends fitnah - never will you possess [power to do] for him a thing against God. Those are the ones for whom God does not intend to purify their hearts. For them in this world is disgrace, and for them in the Hereafter is a great punishment." (5:41)

"Whoever disbelieves in God after his belief... except for one who is forced [to renounce his religion] while his heart is secure in faith. But those who [willingly] open their breasts to disbelief, upon them is wrath from God, and for them is a great punishment." (16: 106)

These and other similar verses in the Qur'an show that the position of wisdom is in heart. Therefore, heart is the place of human wills and because knowledge is a prerequisite of will while heart is the place of knowledge and will, so the subject of both of them is heart; so, the audience and the being to be rewarded and punished is heart and the acts related to it, and they have a close connection with human ego. Since prophet thinkers interpret the seventh verse of al-Qaf chapter: "heart is the thing with which humans think and therefore differentiate right from wrong and good from bad", it can be concluded that speech is taken from inspiration speech which considers heart as a center having three dimensions: wisdom and comprehension as one, affection and action (see: al-Kulayni 1997: I/64). 
These three dimensions, i.e. comprehension ${ }^{1}$, affection ${ }^{2}$ and actions $^{3}$ are attributed to heart in the Qur'an. These three dimensions are related to each other in such a way that wisdom and comprehension have a role in forming emotional states such as love and hatred, and these emotional states result in action; therefore, of these mentioned dimensions of heart, wisdom is the main position of heart and the other two dimensions are related to it. In verse 179 of chapter al-A'raf, the term "jurisprudence", which means exact understanding and comprehending of the reality, is attributed to heart. The above verses and many other verses in the Qur'an show that the Qur'an believes that heart is the position of intellection, thought and comprehension; in many verses, heart, or its place which is the chest, has been mentioned for this; and the term "mind", or its place which is the "head", has never been used for the concepts of intellection and comprehension.

\section{Conclusion}

Nowadays, in modern science, this issue has been proved. For example, let us consider visual sense. Suppose you see a picture; now, take into account how it gets formed in the brain. The retina image never appears in the same way as it does appear in the brain, but, at first, the sunlight that is reflected from a tree enters central pupil of the eyes, and after passing through the lens, a converted image of the object is formed on the retina and can cause physical and chemical change (sensory stimulations). But this is not the whole operation of seeing. If a person were etherized, the same would happen to him. So, in order that the action is realized, we still need other things. The retina is a page that is composed of a large number of sensory nerves that are stimulated by the light; it sends slight movement to the optic nerve and this nerve sends this slight movement to the visual part of brain; at the final stage, a schema or a series of neural activity appears like a code So far, all the above things can be explained by physics and chemistry. The point here is that a person is unaware of these reactions. So, it is true to say

1 "And We have placed over their hearts coverings, lest they understand it, and in their ears deafness. And when you mention your Lord alone in the Qur'an, they turn back in aversion." (17: 46)

2 "So by mercy from God, [O Muhammad], you were lenient with them. And if you had been rude [in speech] and harsh in heart, they would have disbanded from about you. So, pardon them and ask forgiveness for them and consult them in the matter. And when you have decided, then rely upon God. Indeed, God loves those who rely [upon Him].” (3: 159)

"God does not impose blame upon you for what is unintentional in your oaths, but $\mathrm{He}$ imposes blame upon you for what your hearts have earned. And God is Forgiving and Forbearing." (2: 225) 
that perception is to some extent dependent on the chemical and physical world. But, in general, it cannot be convertible and reduced to it. For example, a book is related to the paper and glue and ink, but this is not the whole book, so we can say that our perceptions are dependent on our senses, but they cannot be reduced to physical and chemical properties of matter. That the physiological and chemical reactions are of brain are necessary for sensory perception but it isn't equal to the process of perception. Therefore, in quantum worldview, chemical and physical reactions are not considered the significant status. Wilder Penfield the present century neurologist believes that the spirit is the guardian of brain and other organs, and mind and brain are not responsible for the unity of everything that we experience (Robert \& George 2007: 71-70). Robert Augros and George Stanciu believe that the unity of our conscious experiences is provided by our soul - not by the neurosurgical system; they believe that brain is like a complex computer at the highest level. But, just like the computer, it should be managed by a superintend soul. He emphasizes that if we have expected that soul is found in one part of the brain; such is the expectation that planner is the computer itself or a part of it (see: ibid.).

Received: March $10^{\text {th }}, 2014$

Accepted: April 29 $9^{\text {th }}, 2014$

\section{References}

The Holy Qur'an.

Ali ibn Abi Talib (1992), Nahj al-Balagha, ed. Razi, Sayyid Sharif, translated by Asadollah Mobashsheri, $5^{\text {th }}$ ed., Tehran, Daftar-e Nashr-e Farhang-e Eslami.

Al-Ghazali, Muhammad (1973), Ihya 'Ulum al-Din, translated by Mo'ayyedoddin Kharazmi, Tehran, Asatir.

Al-Jawhary, Isma'il ibn Hamad (1998), as-Sihah - Taj al-Lugha va Sihah al-'Arabiyya, ed. Ahmad Abdul-Ghafoor al-Attar, translated by Gholamreza fadaei, Tehran, Museum Library and Parliament Document Center.

Al-Kulayni, Abu Ja'far Muhammad (1997), Usul al-Kafi, translated by Javad Mostafawi, Tehran, Daftar-e Nashr-e Farhang.

Al-Majlisi, Muhammad Baqir (1987), Bihar al-anwar, Beirut, Daru ihya at-turas al-Aarabi.

Al-Raghib al-Isfahani (1985), Mufradatu Alfaz al-Qur'an al-Karim, Qom.

Golshani, Mohammad (2001), Tahlili az Didgah-ha-ye Falsafi-ye Fizikdanan-e Mo'aser, Tehran, Foruzan-ruz. 
Guenon, Rene (2006), The Reign of Quantity and the Signs of the Times, translated by Ali Mohammad Kardan, Tehran, Samt.

Iravani, Mahmoud \& Khodapanahi, Mohammad Karim (2006), Ravan-shenasi-ye ehsas va edrak, $10^{\text {th }}$ ed., Tehran, Samt.

Karbasi-zadeh, Amir Ehsan \& Sheykh Rezaei, Hosein (2011), Falsafe-je Zehn, Tehran, Hermes.

Kuhn, Thomas (2005), The Structure of Scientific Revolutions, translated by Abas Zaheri, Tehran, Qesseh.

Mason,Mark,(2008,),"What Is Complexity Theory and What Are Its Implications for Educational Change?", in: Journal of Educational Philosophy and Theory 40 (1): 35-49.

Mufadhal ibn Umar (2003), at-Tawheed, translated by Abol-Hassan Hoseini, Qom, Rouhani.

Robert, Augros \& George, Stanciu (2007), The New Story of Science, translated by Badiollah Roshandel, Tehran, Bahjat.

Seif, Ali Akbar (2006), Ravan-shenasi-ye Tarbiyati, Tehran, Douran. 